\title{
Heavy and Trace Elements in Some Brands of Rice Consumed in Delta State, Nigeria
}

\author{
K. Emumejaye \\ Science Laboratory Technology Department Delta State Polytechnic, P.M.B 5, Ozoro, Nigeria
}

\begin{abstract}
Determination of trace elements and heavy metals, copper (Cu), Zinc (Zn), Iron (Fe), Nickel $(\mathrm{Ni})$,beryllium ( $\mathrm{Be})$, cadmium $(\mathrm{Cd})$, chromium $(\mathrm{Cr})$,mercury $(\mathrm{Hg})$ and Lead $(\mathrm{Pb})$ concentration in rice samples purchased from the major markets in Delta State were carried out using Atomic Absorption Spectrometry. The metals detected in rice samples ranged from 0.05 to $14.87 \mathrm{mg} / \mathrm{kg}$ of $\mathrm{Zn}, 0.08$ to $15.33 \mathrm{mg} / \mathrm{kg}$ of $\mathrm{Fe}$, $<1.00$ to $22.73 \mathrm{mg} / \mathrm{kg}$ of $\mathrm{Pb},<0.05$ to $2.82 \mathrm{mg} / \mathrm{kg}$ of $\mathrm{Cu}$, and $<0.05$ to $2.37 \mathrm{mg} / \mathrm{kg}$ of Ni. For mercury the values were 0.001 for all samples. It was not $<0.05 \mathrm{mg} / \mathrm{Kg}$ for $\mathrm{Cd}, \mathrm{Cr}, \mathrm{Be}$ and $\mathrm{Hg}$. Overall, the present study revealed that the levels of the trace elements were generally below permissible limits. However, Pb and Fe were found to be of high concentrations in some samples. These levels compare well with those reported for rice from some other parts of the globe.
\end{abstract}

Keywords: Chemical properties, heavy elements, macronutrients, micronutrients, trace elements

\section{Introduction}

Rice is the second most prevalent cereal crop in the world with an annual global production of approximately 600 million tons. It is the staple food of most Asian countries, with a daily consumption per person of between 200 and $400 \mathrm{~g}$. Trace elemental analysis of this crop and its products is therefore important on an essential, nutritional and toxicological level. The analysis of heavy metals is of particular relevance to human health following numerous incidents such as the mass cadmium poisoning of hundreds of people in Toyama Perfecture, Japan [1] [2]. Nigeria is the second largest importer of rice in the world, buying at least two million metric tons per year from exporting countries like China and Thailand. In Nigeria, rice is eaten with fish, meat and vegetables at least once a day in every home.

Most of the rice consumed in Nigeria is sourced from different soils with different compositions and imported. Some of these soils may have been contaminated and hence this investigation of these rice samples for heavy metals and trace elements. Although trace elements have a role in biochemical functions and biochemical reactions in the human body, if taken in excess could be harmful. For instance excessive intake of zinc has been reported to be toxic [3]. Owing to serious health risk the levels of heavy metals such as Chromium, Nickel, copper, Zinc and iron in foodstuffs this work will provide information of nutritional status of the society and can be reference for public and related institutions to effectively make policies and solution for public health.

\section{Sources of Heavy Metals and Trace Elements}

Heavy metals and trace elements have been traced through biomonitoring where detection of the deposition, accumulation and distribution of trace metals in ecosystems; through the use of different types of vegetations have been successfully monitored. These trace elements are now sourced in the atmosphere, in the soil, plants and food substances. However, the basic source of trace metals to the body is through food since food is the main source where the body gets its nutrition.

The inorganic and organic fertilizers are the most important source of heavy metals to agricultural soil including liming, sewage sludge, irrigation of water and pesticides. Others, particularly fungicides, inorganic fertilizers and phosphate fertilizers have variable levels of $\mathrm{Cd}, \mathrm{Pb}$ and $\mathrm{Zn}$ depending on their sources. Cadmium is of particular concern in plants since it accumulates in leaves at very high levels which may be consumed by animals including humans. Cadmium enrichment also occurs due to the application of sewage sludge, manure and limes.

Industrial sources of heavy metals include mining, refinement: mining operations emit different heavy metals depending on the type of mining. Coal mines are source of $\mathrm{As}, \mathrm{Cd}, \mathrm{Fe}$, etc which enrich the soil around the coalfield directly or indirectly. High temperature processing of metals such as smutting and casting emits metals in particulates and vapour forms. Vapour from heavy metals such as $\mathrm{Pb}, \mathrm{Cd}$ and $\mathrm{Cu}$ combines with water in the atmosphere to form aerosols. 


\section{Pathway for these Heavy Metals and Trace Elements}

These elements are scattered all over both in the atmosphere, in the soil, in plants and plant products. Food being the main source of human nutrition; trace elements have it as a pathway of entering to the human body. These elements are absorbed in plants roots, stems, and leaves are food to human. Also some of these elements are traced to be found in fast foods that are prepared and preserved such as beverages and other minor fast food which their constituents are majority elemental so as to make it fast and simple. Therefore, the pathway for this trace element is majorly through food substances as elements such as Zinc, Nickel, Copper and Chromium are found in some rice samples consumed in Delta State.

\section{Effects of the Heavy Metals and Trace Metals}

The heavy metals investigated were: cadmium $(\mathrm{Cd})$, copper $(\mathrm{Cu})$, lead $(\mathrm{Pb})$, manganese $(\mathrm{Mn})$ and zinc $(\mathrm{Zn})$. Although some of these are essential, all five of these heavy metals are toxic to humans, even at relatively low levels.[4,5,6,7,8,9,10]

Almost all foods are either plants or animal origin. These consist of carbohydrates, fats (lipids), proteins, mineral elements, vitamin, and water. Mineral elements which are needed in small quantity for the metabolism of the body consist mainly of the macronutrients, micronutrients and trace elements. The trace elements are also divided into dietary point of view into three: they are the essential trace elements (macronutrients) which are constituents of hormones, vitamins and catalyst for the enzyme system for metabolic processed in cells and tissues has a very special effect. It can either be the essential or the non essential trace element. Their effect can either be toxic or non toxic and these alters the rate of metabolism in an organism [11].

\section{Chemical Properties of Trace Elements}

Trace elements found in rice are basically metallic elements which are in low proportions. Their concentration determine either they will be toxic or non-toxic. Therefore, their properties are shown as follows;

- Micronutrients: Trace elements have taken the form of micronutrients which are constituents in hormones, vitamins and catalysts for enzymes and metabolism.

- Nutritional importance: Trace elements have of great nutritional importance in many ways such that their absence now is found to be deficiency and causing some inabilities and diseases like anaemia (deficiency of Iron).

\section{Materials and Methods}

Ten samples of different brands of rice were purchased from different major markets in the study area and were analyzed in the laboratory. These brands show a fair representation of the rice consumed in Delta State, Nigeria.

\section{Collection and Preservation of Samples}

The ten (10) samples of rice used for this analytical work were collected from different markets in Delta State. Each sample was wrapped in a sampling bag and labeled with brand's name.

\section{Extraction Procedure}

Determination of the trace elements in these different brands of rice was by the means of Laboratory Atomic Absorption Spectroscopy (PG AA500). This practical has been demonstrated to be applicable to wide variety of samples; types of matrices, in many cases will give complete dissolution of metals of interest.

\section{Determination}

This method used for the determination of metallic elements found in some rice consumed in Delta State is for low concentration of these $t$ elements which are Zinc $(\mathrm{Zn})$, Iron (Fe), Lead (Pb), Copper $(\mathrm{Cu})$,Chromium(Cr), cadmium (Cd) and Nickel (Ni). This method is based on Atomic Absorption Spectroscopy. This was prepared by fusion of some reagents such as Nitric acid of specific gravity of $1.42 \mathrm{~g}$, Hydrochloric acid $1.19 \mathrm{~g}$, filter paper and hotplates for heating to determine the specifications of these elements and their concentration.

\section{Reagents and Apparatus}

The reagents and apparatus used for this experiment is as follows.

1. Nitric Acid $\left(\mathrm{HNO}_{2}\right)$ of specific gravity of $1.42 \mathrm{~g}$.

2. Hydrochloric acid $(\mathrm{HCl})$ of specific gravity of $1.19 \mathrm{~g}$.

3. Beaker of $100 \mathrm{ml}$

4. Filter paper (what man No. 42) 


\title{
Procedure
}

\author{
5. Hot plate
}

- $\quad$ Sample weight of 0.5 - $1.0 \mathrm{~g}$ of dried sample using coning and quartering technique of sample into a beaker washed and containing acid.

- $\quad$ Few drops of deionised water was added to wet the soil (rice) grinded and $5 \mathrm{ml} \mathrm{HNO}_{3}$ also the solid sample were grinded.

- $\quad$ Furthermore, $5 \mathrm{ml}$ of Nitric acid was added to the beaker.

- Heat the mixture on a hot plate in a fume hood until the sample was reduced to about $10 \mathrm{ml}$.

- $\quad$ This was allowed to cool and was filtered and the digested sample was dropped into 100ml volumetric flask and make up to mark with deionsed water.

- Analysis of the filtration for various metals was then made of the interest Atomic Assumption Spectroscopy.

\section{Principle/Theory}

This principle has been based on the absorption of energy valence electrons of ground state atom. Absorbance is directly proportional to the concentration. The absorbance of a known standard and that of the sample is usually compared and calculated or results are plotted graphically to obtain the concentration of the sample.

This is a technique that makes the use of absorption of spectrometry to assess the concentration of an analyte in a sample. It requires standards with known analyte content to establish the relation between the measured absorbance and the analyte concentration and relies, therefore on the Beer - Lambert law. In short, the electrons of the atoms in the atomizer can be prompted to higher orbital's (exited state) for the short period of time (nanoseconds) by absorbing a defined quantity of energy (radiation of a given wavelength). This amount of energy; that is the wavelength is specific electron transition in a particular element. In general, each wavelength corresponds to only one element and the width of an absorption line is only of the order of a few picometers $(\mathrm{pm})$ which gives the technique its elemental selectivity. The radiation flux without a sample and with a sample in the atomizer is measured using a detector and the ratio between two values (the absorbance) is converted to analyte concentration or mass using the Beer-Lambert law.

In order to analyze samples for its atomic constituents, it has to be atomized. The atomizer most commonly used are flames and electro thermal (graphite tube) atomizer. The atom should then be eradicated by optical radiation and the radiation source could be an element - specific line radiation source or a continuum radiation source. The radiation them passes through a monochromator in order to separate the element - specific radiation from any other radiation emitted by the radiation source which finally measured by a detector.

\section{Result and Discussion}

The result obtained from the extraction procedure and the determination of traced elements from 10 samples of major brands of rice consumed in Delta State, Nigeria is as shown in Table 1 below

\begin{tabular}{|c|c|c|c|c|c|c|c|c|c|c|c|}
\hline \multirow[b]{2}{*}{$\mathrm{S} / \mathrm{N}$} & \multirow[b]{2}{*}{$\begin{array}{l}\text { SAMPLE } \\
\text { ID }\end{array}$} & \multirow[b]{2}{*}{$\begin{array}{l}\text { SOURCE } \\
\text { COUNTRY }\end{array}$} & \multicolumn{5}{|c|}{ HEAVY AND TRACE ELEMENTS } & \multirow[b]{2}{*}{$\mathrm{Cd}$} & \multirow[b]{2}{*}{$\mathrm{Cr}$} & \multirow[b]{2}{*}{$\mathrm{Be}$} & \multirow[b]{2}{*}{$\mathrm{Hg}$} \\
\hline & & & $\mathrm{Zn}$ & $\mathrm{Fe}$ & $\mathrm{Pb}$ & $\mathrm{Cu}$ & $\mathrm{Ni}$ & & & & \\
\hline & & & $\mathrm{mg} / \mathrm{Kg}$ & $\mathrm{mg} / \mathrm{Kg}$ & $\mathrm{mg} / \mathrm{Kg}$ & $\mathrm{mg} / \mathrm{Kg}$ & $\mathrm{mg} / \mathrm{Kg}$ & $\mathrm{mg} / \mathrm{Kg}$ & $\mathrm{mg} / \mathrm{Kg}$ & $\mathrm{mg} / \mathrm{Kg}$ & $\mathrm{mg} / \mathrm{Kg}$ \\
\hline 1 & $\mathrm{~A}$ & Thailand & $<0.05$ & 5.33 & 5.45 & $<0.05$ & $<0.05$ & $<0.05$ & 0.06 & $<0.005$ & $<0.001$ \\
\hline 2 & B & Thailand & 9.29 & 12.00 & $<1.00$ & $<0.05$ & $<0.05$ & $<0.05$ & $<0.05$ & $<0.05$ & $<0.001$ \\
\hline 3 & $\mathrm{C}$ & Thailand & 5.23 & 8.67 & 14.55 & 1.82 & $<0.05$ & $<0.05$ & 0.09 & $<0.05$ & $<0.001$ \\
\hline 4 & $\mathrm{D}$ & Nigeria & 5.74 & 15.33 & $<1.00$ & $<0.05$ & $<0.05$ & $<0.05$ & 0.12 & $<0.05$ & $<0.001$ \\
\hline 5 & $E$ & Thailand & 14,37 & 12.00 & 5.45 & $<0.05$ & 2.11 & $<0.05$ & 0.07 & $<0.05$ & $<0.001$ \\
\hline 6 & $\mathrm{~F}$ & Thailand & 10.81 & 2.00 & $<1.00$ & 0.05 & 2.37 & $<0.05$ & $<0.05$ & $<0.05$ & $<0.001$ \\
\hline 7 & $\mathrm{G}$ & Thailand & 14.87 & 8.67 & $<1.00$ & $<0.05$ & 1.84 & $<0.05$ & 0.06 & $<0.05$ & $<0.001$ \\
\hline 8 & $\mathrm{H}$ & Thailand & 44.72 & 12.00 & $<1.00$ & $<0.05$ & 1.05 & $<0.05$ & 0.12 & $<0.05$ & $<0.001$ \\
\hline 9 & $\mathrm{I}$ & Thailand & $<0.05$ & 12.00 & 22.73 & 1.82 & 6.05 & $<0.05$ & 1.15 & $<0.05$ & $<0.001$ \\
\hline 10 & $\mathrm{~J}$ & India & 6,75 & 0.08 & 17.64 & 2.82 & $<0.05$ & $<0.05$ & $<0.05$ & $<0.05$ & $<0.001$ \\
\hline
\end{tabular}

Table 1 shows trace elements values obtained from the 10 samples

Also Table 2 below shows the heavy metals and trace elements obtained in samples and the ones obtained from rice in other countries 


\begin{tabular}{|c|c|c|c|c|c|c|c|c|c|c|c|}
\hline & & \multicolumn{10}{|c|}{ Samples of Rice (Sample ID) } \\
\hline Elements & $\begin{array}{l}\text { Austra } \\
\text { lia } \\
\text { Value* }\end{array}$ & A & B & $\mathrm{C}$ & D & E & $\mathrm{F}$ & G & $\mathrm{H}$ & I & $\mathrm{J}$ \\
\hline $\mathrm{Zn}$ & 13.40 & $<0.05$ & 9.29 & 5.23 & 5.74 & 14.37 & $\begin{array}{l}10.81 \\
\end{array}$ & 14.87 & 4.72 & $<0.05$ & 6.75 \\
\hline $\mathrm{Cu}$ & 1.60 & $<0.05$ & $<0.05$ & 1.82 & $<0.05$ & $<0.05$ & $<0.05$ & $<0.05$ & $<0.05$ & 1.82 & 2.82 \\
\hline $\mathrm{Pb}$ & 19.00 & 5.45 & $<1.00$ & 14.55 & $<1.00$ & 5.45 & $<1.00$ & $<1.00$ & $<1.00$ & 22.73 & 17.64 \\
\hline $\mathrm{Ni}$ & 1.05 & $<0.05$ & $<0.05$ & $<0.05$ & $<0.05$ & 2.11 & 2.37 & 1.84 & 1.05 & 7.82 & $<0.05$ \\
\hline $\mathrm{Fe}$ & $-\overline{----}$ & 5.33 & 12.00 & 8.67 & 15.33 & 12.00 & 2.00 & 8.67 & 12.00 & 12.00 & 0.08 \\
\hline $\mathrm{Cd}$ & 0.73 & $<0.05$ & $<0.05$ & $<0.05$ & $<0.05$ & $<0.05$ & $<0.05$ & $<0.05$ & $<0.05$ & $<0.05$ & $<0.05$ \\
\hline $\mathrm{Cr}$ & 1.99 & 0.06 & $<0.05$ & 0.09 & 0.12 & 0.07 & $<0.05$ & 0.06 & 0.12 & 1.15 & $<0.05$ \\
\hline $\mathrm{Be}$ & ------ & $<0.005$ & $<0.005$ & $<0.005$ & $<0.005$ & $<0.005$ & $\begin{array}{l}<0.00 \\
5\end{array}$ & $<0.005$ & $<0.005$ & $<0.005$ & $<0.005$ \\
\hline $\mathrm{Hg}$ & -------ינ & $<0.001$ & $<0.001$ & $<0.001$ & $<0.001$ & $<0.001$ & $\begin{array}{l}<0.00 \\
1\end{array}$ & $<0.001$ & $<0.001$ & $<0.001$ & $<0.001$ \\
\hline
\end{tabular}

Table 2 present sample values of heavy and trace elements and values from other countries.

*Rahman M.A ${ }^{[12]}$

The recommended maximum permissible limits of these metals in food are shown in Table 3

\begin{tabular}{|l|l|l|}
\hline Metal & $\begin{array}{l}\text { WHO Recommended Permissible Limit in Food } \\
(\mathrm{mg} / \mathrm{Kg})\end{array}$ & Reference \\
\hline Iron $(\mathrm{Fe})$ & 5.0 & {$[13]$} \\
\hline Lead $(\mathrm{Pb})$ & 5.0 & {$[13]$} \\
\hline Cadmium $(\mathrm{Cd})$ & 0.3 & {$[14]$} \\
\hline Nickel $(\mathrm{Ni})$ & 1.5 & {$[15]$} \\
\hline Copper $(\mathrm{Cu})$ & 40 & {$[14]$} \\
\hline Zinc $(\mathrm{Zn})$ & 60 & {$[14]$} \\
\hline Chromium $(\mathrm{Cr})$ & 20 & {$[16]$} \\
\hline Beryllium $(\mathrm{Be})$ & N/A & \\
\hline Mercury $(\mathrm{Hg})$ & N/A & \\
\hline
\end{tabular}

N/A: Not available

.Sample $\mathrm{J}$ indicates high level of $\mathrm{Pb}$ concentration higher than values obtained from Australia and permissible limits. While sample B,C,D,E,G,H and I are of higher values than the maximum permissible values for Fe. Zinc, Chromium, copper and Cadmium in all samples is below the maximum permissible limits. Mercury in all samples is less than $0.001 \mathrm{mg} / \mathrm{Kg}$.

\section{Conclusion}

This study reveals that there is a high level of $\mathrm{Pb}$ and Fe contamination in some samples. This may pose various health risks to the consumer especially the very young children, pregnant women and immunocompromised persons.

The various agencies or authorities responsible for regulation of food should periodically monitor the concentration of these elements in imported and locally produced rice which is consumed in the study area to avoid the harmful effects of accumulation of high concentration levels.

\section{References}

[1]. Dickson, H. Food Safety Series - Determination of trace element in rice products by flame and graphite furnance atomic absorption spectrometry, Thermo Fisher Scientific, Cambridge,UK.2009

[2]. Peoples Republic of China, FAIRS Product Specific Maximum Levels of Contaminants in Food, 2006

[3]. Somer,E \& Garrison, R.G (1995). The nutrition desk reference ( $3^{\text {rd }}$ Edition, Kents Publishing Inc., New Cannan, Connecticut, USA,1995 pp182-229).

[4]. Mejare M, Bulow L. Metal-binding proteins and peptides in bioremediation and phytoremediation of heavy metals. Trends Biotechnol. 2001;19(2):67- 73. http://dx.doi.org/10.1016/S0167-7799(00)01534-1

[5]. Okoye, C.O.B, Ugwu J.N. Impact of environmental cadmium, lead, copper and zinc on quality of goat meat in Nigeria. Ethiopia Bull Chem Soc. 2010;24(1):133-138.

[6]. Bell R. W, Dell B. Micronutrients for sustainable food, feed, fiber and bioenergy production. 1st ed. Paris: International Fertilizer Industry Association; 2008.

[7]. Gaetke L M, Chow KC. Copper toxicity, oxidative stress and antioxidant nutrients. Toxicology. 2003;189:141-163. http://dx.doi.org/10.1016/S0300 -483X(03)00159-8

[8]. Aschner L J, Aschner M. Nutritional aspects of manganese homeostasis. Mol Asp Med. 2005;26(4-5):353-362. http://dx.doi.org/10.1016/i.mam. 2005.07.003

[9]. Lenntech Water Treatment Purification. Manganese [homepage on the Internet]. No date [accessed 2010 June]. Available from: http://www. lenntech.com/periodic/elements/mn.htm 
[10]. Adriano D. C. Trace elements in terrestrial environments: Biogeochemistry, bioavailability and risks of metals. 2nd ed. New York: Springer Verlag; 2001.

[11]. Joseph, E ,Nasiru,R. \& Ahmed, Y.A. Trace elements in some Nigerian commercial infant milk and cereal formulae. Annals of Biological Research, 2011,2(2): 351-360

[12]. Rahman, M.M. Consumption of arsenic and other elements from vegetables and drinking water from an arsenic-contaminated area of Bangla- desh. J. Hazard. Mater 2012.

[13]. FAO/WHO (2011); Joint FAO/WHO food standards programme codex committee on contaminants in foods, fifth session pp 64-89

[14]. Codex Alimenttarius. Maximum levels for cadmium in cereals, pulses and legumes: Joint FAO/WHO standards, CAC/GL 39.c2001 Retrieved from: http://img.21food.cn/img/biaozhun/20100729/180/11294167.pdf

[15]. Masona C. Assessment of Heavy Metal Accumulation in Wastewater Irrigated Soil and Uptake by Maize Plants (Zea Mays L) at Firle Farm in Harare; Journal of Sustainable Development 2011; Vol. 4, No 6. PP 132-137 Published by the Canadian Centre of Science and Education available online www.ccsenet.org/jsd

[16]. Singh, A., Sharma, R. K. Agrawal, M. \& Marshall, F. M. Risk assessment of heavy metal toxicity through contaminated vegetables from waste water irrigated area of Varanasi, India; Tropical Ecology 2010; 51(2S): International Society for Tropical Ecology; pp 375-387; available online www.tropecol.com 